\title{
APLIKASI TEKNOLOGI BIOENGINEERING JEBAKAN SEDIMEN DI SUB DAS CITANDUY HULU
}

\author{
Hasmana Soewandita dan Nana Sudiana \\ Pusat Teknologi Sumberdaya Lahan Wilayah dan Mitigasi Bencana - BPP Teknologi \\ JI. MH. Thamrin No. 8 Jakarta Pusat \\ Telp. 021-3169672/52, E-mail : hsoewandito@yahoo.com
}

\begin{abstract}
Abstrak
Citanduy watershed has been classified as a critical watershed in West Java. Sedimentation load at Citanduy watershed reach 5 milion cubic meters/years. It is indicated that lagoon area "Segara Anakan" was decreased about 823 hectars. Land use changes for cultivation area at Citanduy upland causes acceleration land degradation. Various efforts of the civil engineering and vegetative approach have been applied to control erosion and sedimentation. Alternative technology for controlling soil erosion and sedimentation is the application of sediment trap bioengineering. It is application on micro catchment area, environment-friendly, and easily adapted for the farmers community. The main for material of bioengineering sediment trap is made of Bamboo. Results of design that is applied in the critical area at Bukit Bitung up land (Citaduy upland) Kecamatan Tambaksari, Ciamis Region, measuring the width between $100 \mathrm{~cm}$ to $150 \mathrm{~cm}$, whereas the height are between $80 \mathrm{~cm}$ to $100 \mathrm{~cm}$. The application of this technology is effective sediment traps for micro catcment area of $<5$ hectars. Therefore for a broad cachment area more sediment traps are required. In a period of not more than 1.5 month, the sediment trap has been able to capture sediments up to $1 \mathrm{~m}^{3}$ per unit. The performance of sediment traps bioengineering also shown that bamboo as main components has grown up to not more than 30 days. The trapped sediments were restored back to the land for agricultural purposes after being add by agricultural waste. Sediments that have been processed at the same time also functions as soil amelioration or soil improvement.
\end{abstract}

Key words : degradasi lahan, jebakan sedimen, bioengineering, sedimentasi, ameliorasi

\section{PENDAHULUAN}

\subsection{Latar Belakang}

DAS Citanduy merupakan salah satu daerah aliran sungai di Jawa Barat yang kondisinya kritis. DAS Citanduy mempunyai luasan $352.080 \mathrm{Ha}$ dan terdiri lima (5) sub DAS yaitu Citaduy Hulu (74.800 ha), Cimuntur (60.500 $\mathrm{Ha})$, Cijolang $(48.030 \mathrm{Ha})$, Ciseel $(96.500 \mathrm{Ha})$ dan Cikawung (72.250 Ha). Dilihat dari administrasi wilayah DAS Citanduy berada di 6 kabupaten yaitu Kabupaten Tasikmalaya, Ciamis, Majalengka, Kuningan, Garut dan Cilacap. Kekritisan DAS ini juga ditunjukkan oleh kondisi penutupan lahan hutan yang semakin menyusut. Indikasi degaradasi lahan yang telah berlanjut pada daerah aliran sungai Citanduy juga ditunjukkan kondisi kualitas perairan yang semakin buruk baik kualitas fisik dan kimianya.

Dari segi aspek kualitas fisik nampak nyata bahwa kondisi kekeruhan air sungai yang berwarna coklat kemerahan mengindikasikan aliran sungai ini membawa beban sedimen yang luar biasa. Berdasarkan data pada tahun 2007, beban sedimentasi aliran sungai Citanduy berkisar 5 juta $\mathrm{m}^{3}$ /tahun. Indikator lain juga dapat ditunjukkan terjadinya sedimentasi di segara anakan yang menjadi tempat akhir pengendapan sedimen. Luas laguna Segara Anakan pada tahun 2008 tinggal $823 \mathrm{Ha}$, sedangkan pada pada tahun 1903 luas perairan laguna Segara Anakan masih $6.450 \mathrm{Ha}$.

Sedimentasi ini merupakan bentuk dari adanya proses erosi yang terjadi di daerah hulu. Degradasi lahan didaerah hulu DAS Citanduy ditunjukkan adanya kawasan berlereng curam yang dimanfaatkan untuk kawasan budidaya pertanian. Kegiatan budidaya pertanian di kawasan hulu tidak mengikuti kaedah pertanian konservasi. Idealnya kawasan upland Citanduy yang dimanfaatkan oleh masyarakat untuk aktivitas budidaya dilakukan dengan penerapan pertanian konservasi. Secara ekologis, kawasan lahan yang mempunyai kelerengan > 45\% dipergunakan untuk kawasan lindung atau konservasi ${ }^{6)}$.

Mengingat tuntutan situasi sosial dan ekonomi, tidak dihindari desakan masyarakat akan kebutuhan lahan untuk produksi pangan mendesak kawasan yang seharusnya untuk kawasan konservasi dialihkan atau dimanfaatkan untuk lahan pertanian sebagi tempat untuk produksi pangan. Sebagai kasus nyata fenomena 
ini dapat ditunjukkan di kawasan perbukitan Gunung Bitung di sub DAS Citanduy Hulu. Erosi nampak nyata terjadi di kawasan ini dikarenakan kegiatan pertanian di kawasan berlereng tidak menerapkan kaedah konservasi tanah dan air.

Upaya-upaya yang dapat direkomendasikan sehubungan dalam rangka penanganan erosi/sedimentasi dapat dilakukan dengan berbagai hal. Dalam rangka upaya untuk menurunkan tingkat erosi tanah baik pada lahan pertanian maupun lahan kawasan hutan dapat didekati pendekatan vegetatif yaitu pola agrokonservasi maupun agroforestry ${ }^{4)}$.

Pendekatan vegetatif dapat dipadukan dengan pendekatan yaitu sistem terasering. Hal-hal seperti kegiatan diatas telah lama dikenal dan diaplikasikan ditingkat masyarakat. Namun demikian tidak dipungkiri kegiatan diatas masih belum sempurna tingkat keefektifannya dalam menanggulangi dampak lanjutannya yaitu sedimentasi yang masih terjadi di badan sungai.

Opsi yang masih bisa dijadikan alternatif sebagai upaya untuk menanggulangi pencegahan sedimentasi adalah bagaimana upaya menghambat sedimen hasil proses erosi masuk ke badan sungai yaitu dengan konsep pembangunan teknologi bioengineering jebakan sedimen. Jebakan atau penangkap sedimen ini mengupayakan sedimen yang terangkut oleh air limpasan ditangkap pada suatu wadah tertentu dengan konstruksi bahan yang bisa tumbuh dan bersifat lokal.

Sehingga dengan konstruski yang ramah lingkungan, bersifat lokal, mudah diaplikasikan ditingkat petani dapat diupayakan pengendalian aliran sedimen masuk ke badan sungai. Sedimen hasil jebakan ini juga dapat dikembalikan kembali ke lahan pertanian dan dapat diupayakan/ditingkatkan kesuburannya setelah diproses sebagai fungsi ameliorasi lahan.

\subsection{Tujuan}

Melakukan desain dan kajian penerapan teknologi bioengineering jebakan sedimen untuk menanggulangi atau mengurangi sedimentasi sungai di sub DAS Citanduy Hulu.

\section{METODOLOGI}

\subsection{Lokasi}

Lokasi kegiatan desain dan aplikasi sedimentrap bioenginering dilakukan di perbukitan kritis Gunung Bitung kawasan lahan kritis Citanduy hulu yang secara adiministrasi wilayah masuk Kecamatan Tambak Sari Kabupaten Ciamis. Waktu pelaksanaan dilakukan bulan Oktober 2007 hingga April 2008.

\subsection{Bahan dan Alat}

Bahan yang digunakan untuk kegiatan kajian ini adalah peta lahan kritis, data sekunder dari dokumen kajian tentang DAS Citanduy, bambu, batu kali. Peralatan yang digunakan untuk aplikasi yaitu alat-alat pertanian.

\subsection{Metoda}

Metoda yang digunakan dalam rangka kegiatan ini adalah :

\subsubsection{Penelusuran literatur}

Penelusuran literatur digunakan dalam rangka untuk mendapatkan informasi-informasi yang berkaitan dengan kondisi karakteristik biofisik, dan peta pendukung (peta lahan kritis).

\subsubsection{Perencanaan Desain}

Perencanaan desain dilakukan dengan dilakukan survei lapang terlebih dahulu. Informasi lokasi studi yang mengindikasikan kondisi kekritisan lahan (dilakukan ground ceck) dengan survei lapang. Pengamatan fenomena erosi yang terjadi dilahan dipetakan diatas kertas dan ditandai dengan peletakan calon lokasi konstruksi jebakan sedimen. Pelaksanaan selanjutnya dengan dilakukan pengukuran dilapangan pada alur-alur erosi meliputi lebar, kedalaman serta jumlah sediment trap yang akan diaplikasikan dalam alur-alur erosi.

\subsubsection{Pelaksanaan Aplikasi dan Evaluasi}

Aplikasi jebakan sedimen dilapangan dilakukan berdasarkan hasil perencanaan desain dengan mengacu pada hasil pengukuran dilapangan. Sehingga penempatan atau konstruksi jebakan sedimen sesuai dengan tipe yang akan diaplikasikan, apakah tipe dua lapis atau tipe satu lapis. Pemilihan tipe ini ditentukan oleh lebar dan dalamnya alur erosi. Sedangkan untuk evaluasi kinerja jebakan sedimen dapat dilakukan pengamatan apakah fungsi jebakan sedimen dapat berfungsi dengan baik yaitu dengan mengukur box sedimen yang terisi oleh sedimen hasil sedimen yang terangkut oleh air limpasan. Pengamatan juga dilakukan pada konstruksi jebakan sedimen yang terbuat dari bahan bambu apakah tumbuh atau tidak.

\section{PROFIL BIOFISIK SUB DAS CITANDUY HULU}

\subsection{Karakteristik Lahan}

Kemampuan lahan adalah karakteristik lahan untuk tujuan tertentu seperti areal budidaya atau budidaya pertanian. Faktor-faktor yang 
mempengaruhi kemampuan lahan adalah terutama kondisi biofisik lahan, yaitu ketinggian tempat, kelerengan, drainase, tekstur, erosi, dan kedalaman tanah. Karakteristik lahan Sub DAS Citaduy Hulu disajikan pad Tabel 1.

Tabel 1. Karakteristik lahan di sub DAS Citanduy Hulu

\begin{tabular}{|l|l|r|r|}
\hline No & Kelerengan (\%) & Luas (ha) & \% luas \\
\hline 1. & $0-8$ & 5.377 & 7 \\
\hline 2. & $8-15$ & 23.521 & 31 \\
\hline 3. & $15-25$ & 15.392 & 21 \\
\hline 4. & $25-45$ & 22.693 & 30 \\
\hline 5. & $>45$ & 7.815 & 11 \\
\hline
\end{tabular}

Sumber: BRLKT Citanduy dan Cisanggarung (1999)

\subsection{Tipe Tanah}

Jenis tanah yang ada di sub DAS Citanduy Hulu adalah Kambisol, Gleisol, Latosol, Mediteran dan Podsolik Merah Kuning. Tanah dari jenis Latosol mendominasi luasan sub DAS yaitu menempati arteal seluas $44.924 \mathrm{Ha}$ atau sekitar $60 \%$ areal. Secara rinci luasan setiap jenis tanah pada setiap sub DAS disajikan pada Tabel 2.

Tabel 2. Luasan setiap tipe tanah pada sub-sub DAS Citanduy

\begin{tabular}{|l|l|r|r|}
\hline No. & \multicolumn{1}{|c|}{ Tipe Tanah } & Luas (ha) & \% luas \\
\hline 1. & Kambisol, Gleisol & 28.153 & 38 \\
\hline 2. & Latosol & 44.924 & 60 \\
\hline 3. & Mediteran & - & - \\
\hline 4. & $\begin{array}{l}\text { Podsolik Merah } \\
\text { Kuning }\end{array}$ & 1.723 & 2 \\
\hline
\end{tabular}

Sumber: BRLKT Citanduy dan Cisanggarung (1999)

\subsection{Iklim}

Berdasarkan klasifikasi iklim Schmidt dan Ferguson (1951), tipe iklim di sub DAS Citanduy hulu adalah tipe iklim $A$, atau berdasarkan klasifikasi iklim Koppen (1918), skema iklim yang digunakan adalah $A_{f a}$. Berdasarkan pada klasifikasi zona agro-klimat (Oldeman, 1979), Citanduy hulu berada pada zona B2. Karakteristik iklim pada sub DAS Citanduy Hulu, rata-rata curah hujannya $3.066 \mathrm{~mm}$, jumlah bulan basah 7 - 9 bulan, kelembabannya $79-82 \%$ dan suhu udara antara $21-26^{\circ} \mathrm{C}$.

\subsection{Vegetasi}

Vegetasi tutupan lahan di DAS Citanduy secara umum terdiri dari tanaman tahunan, yaitu jenis hortikultura/buah-buahan, dan tanaman hutan. Vegetasi di kawasan hutan lindung didominasi oleh jenis-jenis seperti rasamala (Altingia excelsa), puspa (Schima noronhae), dan mahoni (Swietenia macrophylla). Sedangkan di hutan produksi jenis-jenis yang dominan adalah jati (Tectona grandis), dan pinus (Pinus merkusii).

Selain itu juga ditemukan vegetasi dalam bentuk tanaman campuran antara tanaman hutan/pohon dengan tanaman tahunan yaitu dengan konsep agroforestry. Pohon yang dikembangkan dalam agroforestry adalah sengon (Paraserianthes falcataria), mahoni (Swietenia macrophylla), dan jati (Tectona grandis). Di luar kawasan hutan dan agroforestry, lahan pertanian ditanaman oleh tanaman seperti padi sawah, sayuran, ketela pohon, kacang-kacangan. Sedangkan jenis tanaman perkebunan dan hortikultura adalah kelapa, cengkeh, karet, dan buah-buahan.

\subsection{Tata Guna Lahan}

Tata guna lahan di Sub DAS Citanduy Hulu sebagian besar didominasi penggunaannya sebagai lahan budidaya perkebunan dan kebun campuran seperti kebun buah-buahan, lahan perkebunan, dan agroforestry yaitu mencapai $32.879,24 \mathrm{Ha}$. Urutan kedua adalah lahan sawah mencapai $19.534,29 \mathrm{Ha}$. Hutan negara mencapai luasan 13.639.29 Ha, sedangkan permukiman mencapai luasan 8.600,46 Ha. Secara rinci kondisi tata guna lahan di Sub DAS Citanduy Hulu disajikan pada Tabel 3.

Tabel 3. Tata guna lahan di sub DAS Citanduy Hulu

\begin{tabular}{|l|l|r|r|}
\hline No. & Tata Guna Lahan & Luas (ha) & \% luas \\
\hline 1. & Hutan Negara & $13.639,29$ & 18.2 \\
\hline 2. & $\begin{array}{l}\text { Budidaya Kebun } \\
\text { Campuran }\end{array}$ & $32.879,24$ & 44.0 \\
\hline 3. & Sawah & $19.534,29$ & 26.1 \\
\hline 4. & Permukiman & $8.600,46$ & 11.5 \\
\hline 5. & Lainnya & 146,72 & 0.2 \\
\hline & TOTAL & $74.800,00$ & 100.0 \\
\hline
\end{tabular}

Sumber: BRLKT Citanduy dan Cisanggarung (1999)

\section{PERMASALAHAN LAHAN}

Hasil survei lapang dibeberapa tempat menyangkut lahan kritis yang diduga memberikan kontribusi penurunan kualitas air (sedimentasi sungai) di DAS Citanduy hulu mengarah pada lokasi wilayah Kecamatan Tambak Sari. Adapun permasalahanpermasalahan yang ditemui di kawasan ini berkaitan dengan erosi dan sedimentasi akan dijelaskan pada sub bab berikut. 


\subsection{Kondisi Penutupan Lahan Pada Tanah Terlantar}

Tanah terlantar dimana pengelolaan tanah minimal bahkan tidak dikelola sama sekali merupakan potensi besar dalam menyumbang erosi tanah. Parameter tingkat pengelolaan, kondisi penutupan merupakan komponen penting terhadap besaran erosi yang terjadi di atas lahan 1). (Gambar 1).

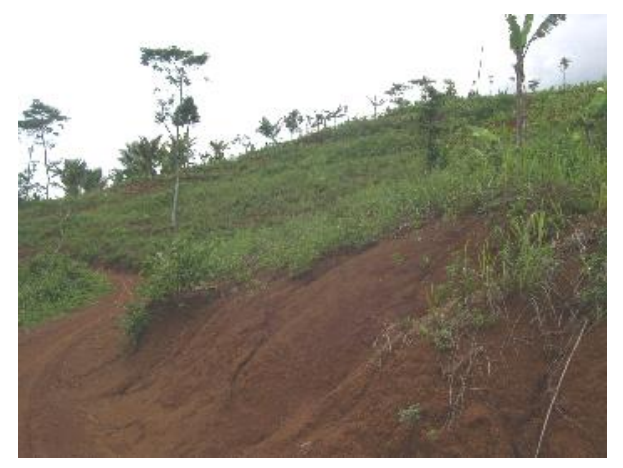

Gambar 1. Kondisi penutupan lahan yang jarang pada lahan terlantar

\subsection{Pengelolaan Lahan Berlereng Curam}

Pengelolaan lahan berlereng curam > $45 \%$ digunakan untuk pertanian tanaman semusim dengan tanpa mengindahkan aspek pengelolaan pertanian konservasi. Upaya terasering telah dilakukan namun maksimalisasi upaya konservasi tanah belum dilakukan, sehingga potensi erosi masih sangat besar, seperti terlihat pada Gambar 2.

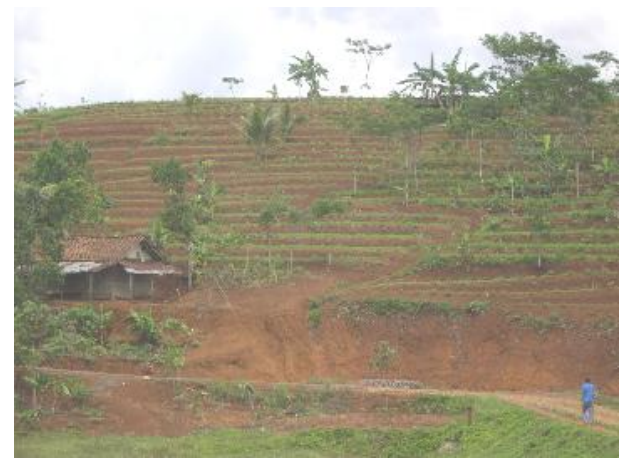

Gambar 2. Pengelolaan lahan berlereng curam untuk budidaya tanaman semusim

\subsection{Pola Pertanaman pada Pertanian Lahan Berlereng}

Pola budidaya tanaman pada lahan berlereng masih ditemui pola pertanian tanaman semusim dan monokultur (Gambar 3). Pada saat panen atau kondisi penutupan lahan masih minimal, daya rusak air hujan pada permukaan tanah lahan pertanian mempunyai energi yang jauh lebih besar apabila dibandingkan dengan pola pertanian multiple croping yang mengkombinasika tanaman keras dan tanaman pangan. Pola multiple croping mengupayakan penutupan lahan tidak hilang sama sekali terutama pada saat panen tanaman pangan. Pola pengolahan tanah dengen pemberian mulsa dari bahan limbah pertanian juga merupakan kegiatan pengelolaan lahan untuk mengendalikan erosi tanah. 2,5 )

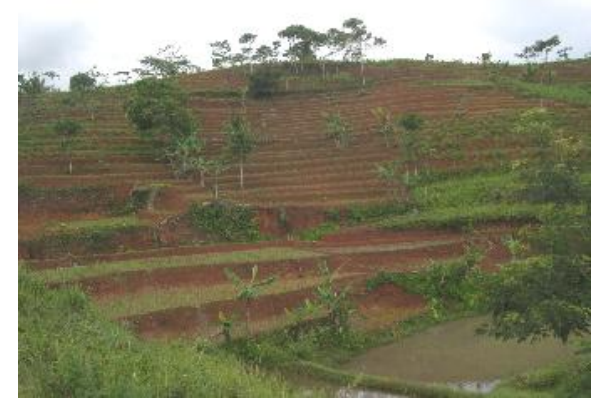

Gambar 3. Pengelolaan lahan pertanian hanya untuk tanaman pangan

\subsection{Kondisi Tanah Rentan Erosi}

Jenis tanah Podsolik di DAS Citanduy yang digunakan untuk lahan pertanian merupakan tanah yang rentan erosi. Fenomena kerentanan ini sangat nyata terlihat pada lahanlahan yang berlereng dan digunakan untuk lahan pertanian tanaman pangan (Gambar 4). Kerentanan yang bisa ditunjukkan dengan faktor erodibilitas tanah yang tinggi secara formulatif berdasarkan persamaan USLE akan mengakibatkan besar erosi tanah sangat tinggi ${ }^{3}$.

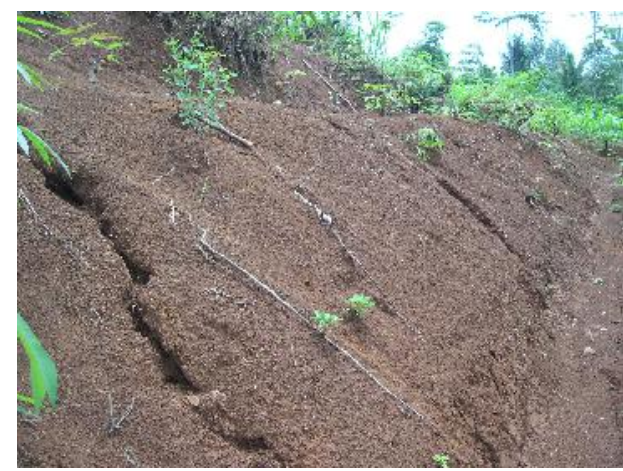

Gambar 4. Tanah di lahan pertanian rentan erosi

\subsection{Saluran Drainase di Lahan Pertanian}

Mengingat kawasan perbukitan (Gunung Bitung) merupakan perbukitan yang kondisinya tergolong kritis dan kini digunakan untuk budidaya tanaman pangan, pengelolaan lahan 
menggunakan sistem terasering dengan kondisi saluran drainase yang mengarah pada potensi erosi saluran. Gradien kemiringan saluran yang tinggi berakibat pada laju aliran permukaan pada saluran yang semakin berpotensi semakin menggerus dasar saluran. Pada kondisi intensitas hujan yang semakin besar sementara gradien kemiringan saluran yang tinggi berakibat pada laju aliran permukaan pada saluran yang semakin berpotensi semakin menggerus dasar saluran. Dampak selanjutnya adalah sedimentasi sungai dan penurunan kualitas air terutama kandungan padatan tersuspensi 3 ). (Gambar 5).

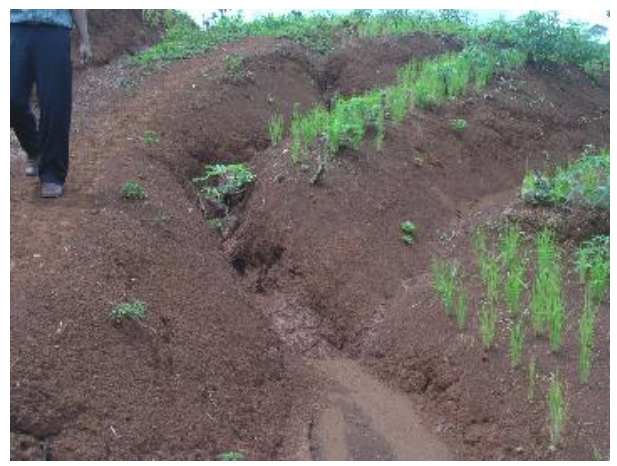

Gambar 5. Erosi saluran di lahan pertanian

\section{PERENCANAAN DESAIN}

\subsection{Lokasi Aplikasi}

Berdasarkan survei pendahuluan yang telah dilakukan dengan merujuk pada permasalahan mendasar DAS Citanduy, lokasi permasalahan erosi/sedimentasi di DAS Citanduy mengarah pada Sub DAS Citanduy Hulu yaitu di kawasan wilayah Kecamatan Tambak Sari dengan detil lokasi di Kawasan Gunung Bitung Desa Kadupandak. Peta lokasi upaya penanganan permasalahan erosi dan sedimentasai seperti terlihat pada Gambar 6 .

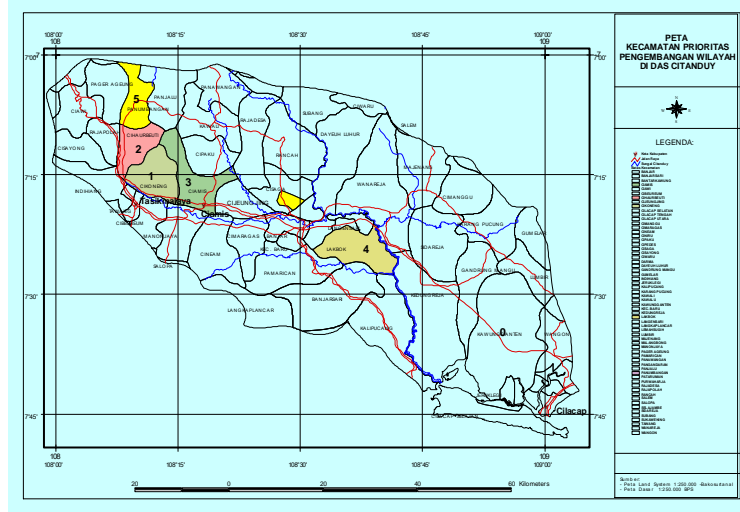

Gambar 6. Lokasi permasalahan erosi/ sedimentasi di Citanduy Hulu

\subsection{Tipe Jebakan Sedimen}

Pengendalian erosi disamping dengan metoda terasering juga dapat dilakukan dengan penerapan teknologi bioengineering jebakan sedimen pada lahan-lahan yang tererosi ataupun pada lahan miring yang mempunyai potensi erosi. Pada prinsipnya penerapan Jebakan sedimen (sediment trap) ini adalah mencegat atau menahan/menangkap sedimen yang berbentuk partikel tanah yang terbawa oleh aliran permukaan. Penangkapan sedimen ini secara tidak langsung mengendalikan kualitas fisik air sungai dan sedimentasi sungai.

Salah satu permasalahan mendasar yang ada di DAS Citanduy adalah sedimentasi sungai yang besarnya berkisar 5 juta $\mathrm{m}^{3} /$ tahun dan hingga kini menjadi permasalahan pendangkalan Segara Anakan di Kabupaten Cilacap. Untuk mengurangi dan mengendalikan terbawanya sedimen ke bada sungai salah satunya adalah pembuatan sediment trap pada alur-alur aliran terkonsentrasi pada suatu lahan baik pada lahan pertanian atupun lahan kebun campuran ataupun hutan.

Penerapan sediment trap pada kegiatan ini lebih bersifat penanganan sedimen akibat erosi lahan yang terjadi pada lahan pertanian atau kebun/hutan yang bisa diadaptasikan atau diintroduksikan kepada petani/masyarakat DAS Citanduy. Beberapa tipe jebakan/penangkap sedimen seperti :

1. Jebakan sedimen pada alur horisontal

2. Jebakan sedimen pada alur tegak lurus kontur

3. Jebakan sedimen pada alur erosi

4. Jebakan sedimen yang berupa ceck dam

\section{(1) Jebakan Sedimen pada alur horisontal}

Salah satu penyumbang sedimentasi sungai adalah kejadian erosi yang terjadi pada lahan budidaya. Saluran-saluran drainase pada lahan miring perlu dilengkapi box atau bangunan sediment trap untuk mencegah pengangkutan partikel tanah oleh aliran permukaan ke badan sungai. Bangunan ini dapat dibuat pada saluran drainase di kawasan budidaya lahan miring/berlereng. Penerapan bangunan jebakan sedimen ini dapat dibangun terpadu dengan sistem pembuatan terasering. Desain sediment trap pada alur horisontal seperti pada Gambar 7.

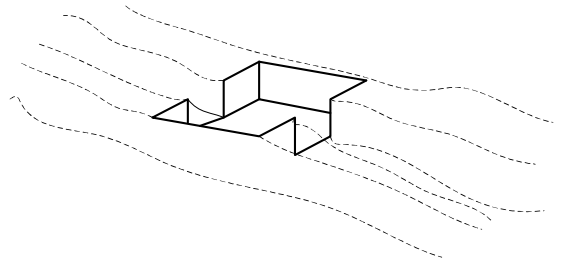

Gambar 7. Jebakan sedimen pada alur horisontal 
(2) Jebakan Sedimen pada alur tegak lurus kontur.

Terkadang dalam aktivitas budidaya pertanian di lahan miring ataupun pada lahan kebun campuran masih dijumpai saluran drainase tegak lurus kontur. Saluran ini sangat berbahaya apabila jalur air tegak lurus memotong kontur tanpa ada suatu hambatan. Daya rusak aliran pada alur ini dapat mengakibatkan penggerusan permukaan saluran yang semakin lama berpotensi menjadi erosi parit. Untuk mengendalikan daya rusak aliran yang sering membawa beban sedimen ini perlu ditahan dengan box-box jebakan sedimen. Penempatan box jebakan sedimen pada alur vertikal seperti disajikan pada Gambar 8

Gambar 8. Jebakan sedimen pada alur vertikal

(3) Jebakan Sedimen pada alur erosi

Jebakan sedimen ini didesain untuk menahan kecepatan aliran permukaan dan menagkap sedimen pada alur-alur aliran permukaan yang tererosi. Aliran yang terkonsentrasi baik pada lahan terbuka/kritis ataupun lahan budidaya pertanian/kebun dan hutan dapat ditahan dengan bangunan penahan yang sederhana dimana bahan bakunya dapat dimabil dari sumberdaya lokal seperti batangbatang pohon kecil atau bambu. Dari aspek ketahanan terhadap waktu, bangunan ini memang tidak tahan lama, akan tetapi teknologi mudah diadaptasikan pada tingkat masyarakat/petani. Desain gambar jebakan sedimen pada tipe ini disajikan pada Gambar 9.

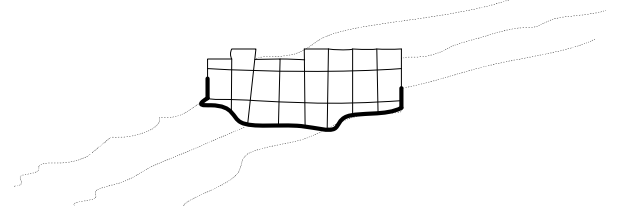

Gambar 9. Sediment Trap pada alur erosi Penangkap Sedimen (Ceck Dam)

Ceck Dam pada hakekatnya berfungsi sebagai penangkap sedimen dalam skala yang lebih besar. Pada ceck dam juga sekaligus difungsikan sebagai penyimpan air, karena pada lokasi tapak penempatan ceck dam ada alur aliran sungai, ada cekungan dan berada pada lembah dengan diapit bukit. Aliran sungai yang berada berada dihulu terkadang bersifat tidak permanent kontinuitas alirannya. Pada saat musim kemarau kering dan pada saat musim hujan sebagai jalur air. Lokasi ceckdam biasanya berada di lahan kritis. Kesempatan air untuk meresap ke tanah sangat sulit sehingga air limpasan cenderung hilang melimpas ke badan sungai. Pembangunan ceckdam sebaiknya diikuti oleh penghijauan kondisi sekitarnya sehingga fungsi ekologi sekitar ceckdam dapat ditingkatkan, jadi bukan semata-mata hanya menampung air hujan atau penampung sedimen akan tetapi sebagai fungsi hidroorologis untuk daerah catchment areanya.

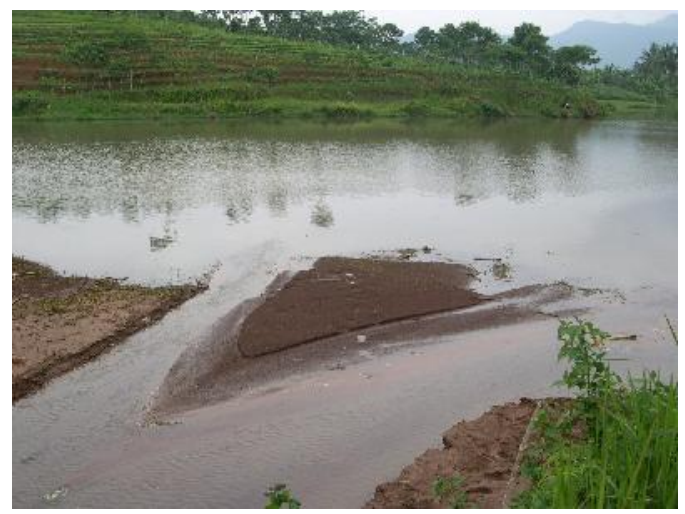

Gambar 10. Ceckdam disamping berfungsi untuk penngkap sedimen juga dapat berfungsi untuk penampung air hujan

\subsection{Desain Teknis}

Dari hasil survei lokasi penempatan sediment trap diperoleh jalur-jalur erosi parit yang arahnya vertikal atau tegak lurus kontur. Jakurjalur aliran ini yang harus dikendalikan kecepatan alirannya sehingga daya rusak/gerus aliran bisa direduksi. Berdasarkan analisis detil dilapangan peletakan konstruksi sediment trap ini maksimal berjumlah tiga (3) unit, namun demikian jumlah ini sangat tergantung kondisi dilapangan. Dimensi jebakan sedimen yang diaplikasikan juga sangat tergantung pada lebar alur erosi.

Dari ground ceck dilapangan dimensi lebar saluran berkisar antara $1 \mathrm{~m}$ hingga $2 \mathrm{~m}$. Sedangkan tipe konstruksi dibedakan menjadi dua tipe yaitu yang pertama tipe dua lapis dan yang kedua tipe satu lapis. Tipe dua lapis untuk kondisi lebar alur antara $1.5 \mathrm{~m}$ hingga $2 \mathrm{~m}$, sedangkan tipe satu lapis untuk kondisi lebar alur $<1.5 \mathrm{~m}$. Gambar detil disain jebakan sedimen yang akan diaplikasikan di kawasan lahan pertanian Bukit Gadung Desa Kadupandak Kecamatan Tambak Sari Kabupaten Ciamis seperti pada Gambar 11 dan Gambar 12. 


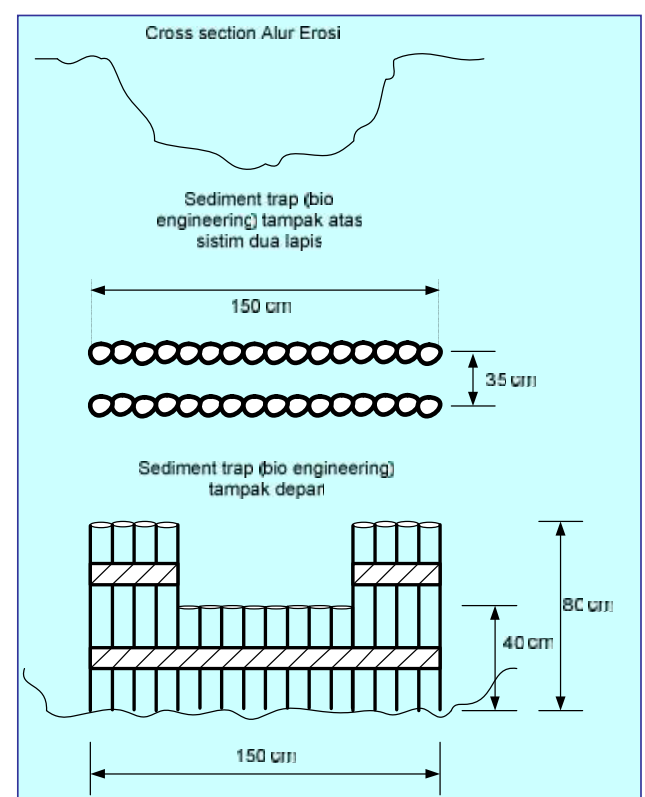

Gambar 11. Desain jebakan sedimen (sediment trap) tipe dua lapis

\section{APLIKASI DAN EVALUASI KINERJA}

\subsection{Bahan Konstruksi}

Bahan yang digunakan dalam konstruks jebakan sedimen (Sediment Trap) adalah Bambu dari jenis Ampel (Bambusa vulgaris Schard). Bambu dari jenis ini sangat cocok untuk konstruksi karena tanaman ini bisa mudah tumbuh dengan stek batang. Untuk bahan konstruksi dipilih bambu yang sudah tua dengan diameter batang antara $10-15 \mathrm{~cm}$.

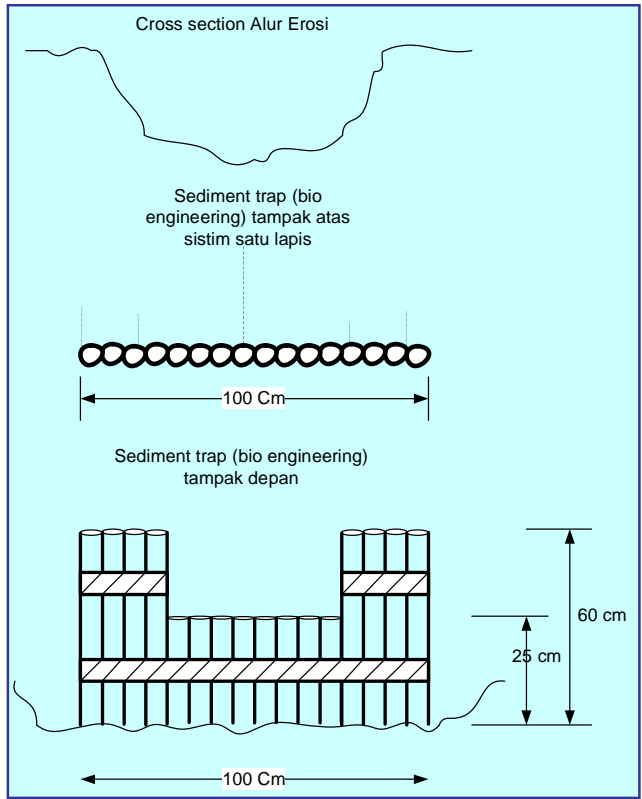

Gambar 12. Desain jebakan Sedimen (sediment trap) tipe dua lapis

\subsection{Konstruksi dan Aplikasi Jebakan Sedimen (Sediment Trap)}

Setelah dilakukan pengukuran dan desain jebakan sedimen. Bambu dipotong dengan ukuran sesuai dengan desain. Gambaran desain jebakan sedimen yang akan diaplikasikan di lapangan seperti disajikan Gambar 11 dan Gambar 12 . Batang bambu dipotong sepanjang $110 \mathrm{~cm}$ dan dipotong sepanjang $90 \mathrm{~cm}$. Batang bambu ditanam dengan cara ditancapkan sedalam kurang lebih $30 \mathrm{~cm}$. Kedalaman ini disamping sudah cukup kuat juga memberi peluang perakaran tanaman bambu dapat tumbuh dengan baik dan berkembang, mencekeram lebih kuat.

Penempatan bambu diletakkan berjajar selebar alur erosi dengan lebar antara $100 \mathrm{~cm}$ hingga $150 \mathrm{~cm}$. Pada alur erosi yang lebar peletakan/penancapan bambu dilakukan dua lapis yaitu lapis bagian dalam dan lapis bagian luar. Diantara dua lapisan bambu tersebut ditambahkan tanah dan dipadatkan setinggi dari potongan bambu tersebut. Pada bagian alur sebelah dalam konstruksi jebakan sedimen (sebelah hulu) dibuat lubang sebagai fungsi tambahan wadah untuk menjebak sedimen yang terangkut aliran air.

Dimensi lubang disesuaikan dengan kondisi alur dan tingkat keterjalan/ kelerengan lahan. Pada bagian sebelah hilir dari konstruksi jebakan sedimen diletakkan batu kali yang fungsinya menahan terjunan air yang telah melewati jebakan sedimen tidak merusak kostruksi seperti fenomena local scouring (penggerusan). Hasil aplikasi jebakan sedimen bioengineering disajikan pada Gambar 13.

\subsection{Kinerja Jebakan Sedimen (Sediment Trap)}

Untuk mengetahui kinerja jebakan sedimen bioengineering dapat dilihat dari dua aspek mendasar. Yang pertama adalah bahwa sedimentrap ini benar-benar bisa berfungsi sebagai penangkap atau penjebak sedimen yang terangkut oleh aliran permukaan yang terkonsentrasi pada jalur erosi atau parit. Sedangkan hal yang mendasar kedua adalah karena menyandang nama "bio" maka konstruksi yang terbuat dari bahan ini benar-benar bisa tumbuh. Sehingga dalam konteks biaya pemeliharaan relatif dengan konstruksi seperti ini tidak dilakukan penggantian bahan (bambu) karena keropos, akan tetapi karena bisa tumbuh pemeliharaannya adalah dengan cara memangkas ranting yang tumbuh terlalu lebat. 


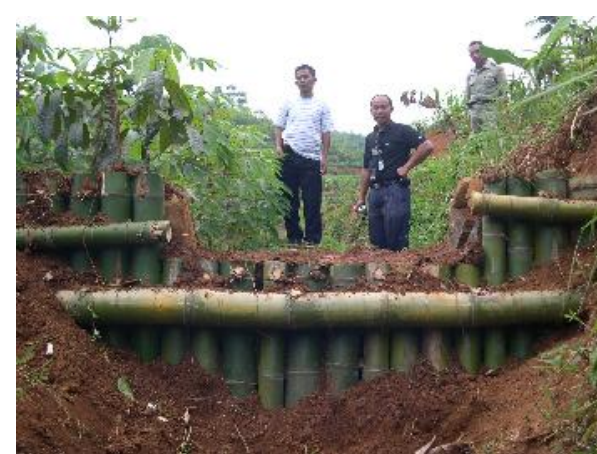

Gambar 13. Konstruksi jebakan sedimen (sediment trap) bioengineering dari bahan bambu (30 Januari 2007)

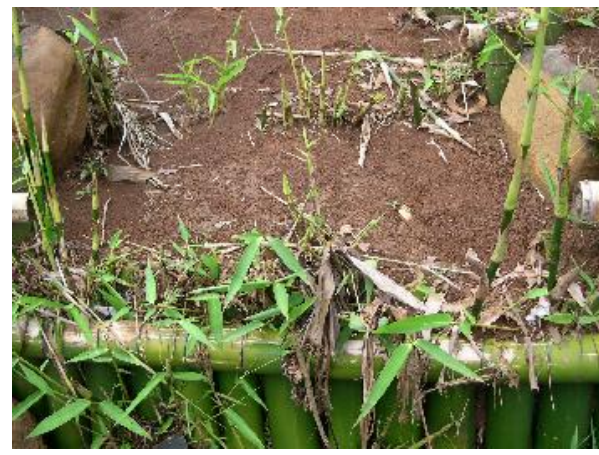

Gambar 14. Jebakan sedimen (sediment trap) bioengineering telah penuh dengan sedimen dan bambu telah nampak tumbuh (4 Maret 2007)

Dengan demikian semakin lama konstruksi jebakan sedimen bioenginering akan semakin kuat karena akar tanaman bambu yang berupa akar serabut mencekeram kedalam tanah disekelilingnya. Hasil kinerja jebakan sedimen baik sebagai fungsi utama penjebak sedimen ataupun kondisi pertumbuhan konstruksi dari bahan bambu disajikan pada Gambar 14. Sejak dilakukan aplikasi pada bulan Februari 2008 hingga waktu pengamatan pada bulan April 2008, jebakan sedimen telah terisi sedimen dan bambu sudah mulai tumbuh.

\section{KESIMPULAN DAN SARAN}

\subsection{Kesimpulan}

- Desain jebakan sedimen (sediment trap) bioengeneering hanya cocok untuk alur erosi dengan lebar kurang dari $1.5 \mathrm{~m}$.

- Lebar alur erosi antara $1 \mathrm{~m}$ hingga $1.5 \mathrm{~m}$ bisa diterapkan tipe jebakan sedimen (sediment trap) bioengineering dua (2) lapis, sedangkan lebar kurang dari $1 \mathrm{~m}$ tipe yang dianjurkan satu (1) lapis.

- Penerapan atau konstruksi jebakan sedimen (sediment trap) bioengineering efektif untuk mikro catcment area dengan luas $<5 \mathrm{Ha}$. Sehingga pada cachment area yang luas dibutuhkan jebakan sedimen yang lebih banyak lagi.

- Dalam jangka waktu tidak lebih dari 1.5 bulan, jebakan sedimen telah mampu menangkap sedimen hingga mencapai $1 \mathrm{~m}^{3}$ per satu unit jebakan sedimen bioengineering.

- Pemeliharaan jebakan sedimen (sediment trap) bioengineering hanya mengangkat/ mengambil sedimen dan dikembalikan lagi kelahan pertanian. Selain itu apabila telah tumbuh rimbun perlu dipotong atau dikurangi trubusan bambu (ranting yang tumbuh).

\subsection{Saran}

Sedimen hasil penjebakan sebaiknya diproses terlebih dahulu dengan menambahkan/ mencampur limbah pertanian dan limbah ternak/kotoran ternak sebelun dikembalikan ke lahan pertanian sehingga sekaligus mempunyai fungsi sebagai ameliorasi atau bahan pembenah tanah yaitu untuk perbaikan kualitas tanah (kesuburan).

\section{DAFTAR PUSTAKA}

1. Arsyad S., 1983. Pengawetan Tanah dan Air. Fakultas Pertanian, IPB.

2. Bull, L and C. Sandretto. 1996. Crop Residue Mangament and Tillage System Trends. Statistical Bulletin US Dept of Agricultural No. 930.

3. Fournier, F. 1956. The effect of climate factor $s$ on Soil Erosion Estimates of Solids Transported in Suspension in Run off. Ass. Int Hydrology, Pub 38.

4. Haeruman H. 1997. Konservasi tanah dan penghijauan dalam program rehabilitasio lahan kritis . Buletin Penghijauan Reboisasi dan Lingkungan Hidup.

5. Sinukaban N., 1990. Pengaruh Pengolahan Tanah Konservasi dan Pemberian Mulsa Jerami terhadap Produksi Tanaman Pangan dan Erosi Hara. Pemberitaan Penelitian Tanah dan Pupuk, Nomor 9, 1990. Pusat Penelitian Tanah dan Agroklimat, Bogor.

6. Sitorus S.R.P., 1989. Survai Tanah dan Penggunaan Lahan. Laboratorium Perencanaan Pengembangan Sumberdaya Lahan. Jurusan Tanah, Fakultas Pertanian, Institut Pertanian Bogor. 
Abstrak

DAS Citanduy tergolong DAS di Jawa Barat yang mempunyai kelas kriteri kritis. Beban sedimentasi DAS Citanduy mencapai hingga 5 juta $\mathrm{m} 3$ /tahun terindikasi dari luas laguna segara anakan yang semakin menyempit dan kini tinggal sekitar 823 ha. Perubahan penggunaan lahan yang mengarah untuk pemanfaatan kawasan budidaya salah satu penyebab percepatan degradasi lahan di kawasan hulu Citanduy. Berbagai upaya dari pendekatan civil engneering dan vegetatif telah diterapkan dalam upaya penanggulangan erosi dan sedimentasi. Salah satu alternative teknologi pengendalian sedimentasi untuk skala mikro cachment area yang ramah lingkungan mudah diadaptasikan ditingkat masyarakat/petani adalah penerapan teknologi bioengineering jebakan sedimen yang terbuat dari bahan utama tanamam Bambu. Hasil desain yang diterapkan dikawasan lahan kritis di bukit gunung Bitung (kawasan sub DAS Citaduy Hulu) Kecamatan Tambaksari Kabupaten Ciamis berukuran lebar antara $100 \mathrm{~cm}$ hingga $150 \mathrm{~cm}$, sedangkan tinggi antara $80 \mathrm{~cm}$ hingga $100 \mathrm{~cm}$. Penerapan atau konstruksi teknologi bioengineering jebakan sediment efektif untuk mikro catcment area dengan luas < $5 \mathrm{Ha}$. Sehingga pada cachment area yang luas dibutuhkan sediment trap yang lebih banyak. Dalam jangka waktu tidak lebih dari 1.5 bulan, jebakan sedimen yang telah dikonstruksi telah mampu menangkap sedimen hingga mencapai $1 \mathrm{~m}^{3}$ per satu unit jebakan sedimen bioengineering. Kinerja jebakan sedimen bioengineering juga ditunjukkan bahwa batang bambu sebagai komponen utama telah tumbuh tidak sampai lebih dari 30 hari. Sedimen yang terjebak atau tertangkap dikembalikan kembali ke lahan pertanian setelah diproses dengan menambahkan limbah pertanian dan kotoran ternak. Sedimen yang telah diproses tersebut juga sekaligus berfungsi sebagai ameliorasi bahan pembenah tanah untuk perbaikan kualitas/ kesuburan tanah.

\begin{abstract}
Citanduy watershed has been classified as a critical watershed in West Java. Sedimentation load at Citanduy watershed reach 5 milion cubic meters/years. It is indicated that lagoon area "Segara Anakan" was decreased about 823 hectars. Land use changes for cultivation area at Citanduy upland causes acceleration land degradation. Various efforts of the civil engineering and vegetative approach have been applied to control erosion and sedimentation. Alternative technology for controlling soil erosion and sedimentation is the application of sediment trap bioengineering. It is application on micro catchment area, environment-friendly, and easily adapted for the farmers community. The main for material of bioengineering sediment trap is made of Bamboo. Results of design that is applied in the critical area at Bukit Bitung up land (Citaduy upland) Kecamatan Tambaksari, Ciamis Region, measuring the width between $100 \mathrm{~cm}$ to $150 \mathrm{~cm}$, whereas the height are between $80 \mathrm{~cm}$ to $100 \mathrm{~cm}$. The application of this technology is effective sediment traps for micro catcment area of $<5$ hectars. Therefore for a broad cachment area more sediment traps are required. In a period of not more than 1.5 month, the sediment trap has been able to capture sediments up to $1 \mathrm{~m}^{3}$ per unit. The performance of sediment traps bioengineering also shown that bamboo as main components has grown up to not more than 30 days. The trapped sediments were restored back to the land for agricultural purposes after being add by agricultural waste. Sediments that have been processed at the same time also functions as soil amelioration or soil improvement.
\end{abstract}

\title{
RIWAYAT PENULIS
}

\section{Ir. Hasmana Soewandita, MSi}

Dilahirkan di Klaten pada tanggal 5 September 1965. Tahun 1990 lulus Sarjana Teknologi Pertanian IPB. Tahun 2002 lulus Pasca Sarjana (S2) IImu Pengelolaan Sumberdaya Alam dan Lingkungan (Sumberdaya Lahan) - IPB. Tahun 1990 - 1994 bekerja pada perusahaan konsultan Kehutanan/Pertanian. Tahun 1994 hingga sekarang peneliti sumberdaya lahan pada Pusat Teknologi Sumberdaya Lahan Wilayah dan Mitigasi Bencana, Kedeputi TPSA - BPPT.

\section{Ir. Nana Sudiana, MSi.}

Dilahirkan di Kuningan tanggal 18 Januari 1968. Luluas S1 Fakultas Kehutanan IPB tahun 1991, S2 Program Studi IImu Lingkungan Universitas Indonesia 2001. Penulis bekerja sebagai peneliti bidang pengendalian lingkungan pada Pusat Teknologi Sumberdaya Lahan Wilayah dan Mitigasi Bencana. Kedeputian TPSA-BPPT. 